Dimitrios Velissaris', Diamanto Aretha ${ }^{2}$, Konstantinos Tsiotsios', Charalambos Gogos', Vasileios Karamouzos ${ }^{2}$

'Department of Internal Medicine, University Hospital of Patras, Rion, Greece

${ }^{2}$ Intensive Care Unit, University Hospital of Patras, Rion, Greece

\title{
Continuous positive airway pressure in the treatment of COVID-19 patients with respiratory failure. A report of six cases with excellent outcome
}

\begin{abstract}
Coronavirus disease 2019 (COVID-19) caused by severe acute respiratory syndrome coronavirus 2 (SARS-CoV-2) is currently considered a significant threat to global health and global economy. This new rapidly spreading virus causes enormous stress to healthcare systems as large number of patients present with respiratory failure, needing intubation and mechanical ventilation. While the industry is racing to meet the rising demand for ventilators, all the alternative respiratory support modalities are employed to save lives in hospitals around the globe. We hereby report 6 patients who were diagnosed with SARS-CoV-2 and treated with continuous positive airway pressure in a negative pressure isolated room in a tertiary center in western Greece. The rapid progression of mild flu-like symptoms to respiratory failure in all patients was controlled with the use of continuous positive airway pressure making this strategy a reasonable alternative to respiratory failure due to SARS-CoV-2 as it may avert intubation and mechanical ventilation.
\end{abstract}

Key words: respiratory failure, coronavirus disease 19, continuous positive airway pressure

Adv Respir Med. 2021; 89: 197-202

\section{Introduction}

Coronavirus disease 2019 (COVID-19) caused by severe acute respiratory syndrome coronavirus 2 (SARS-CoV-2) is currently considered a significant threat to global health and global economy. This new rapidly spreading virus causes enormous stress to healthcare systems as large number of patients present with respiratory failure, needing intubation and mechanical ventilation. While the scientific community is concentrated on finding a specific treatment and/or a vaccine for the new virus, our only option is supportive therapy resulting in a high demand for intensive care unit (ICU) beds and ventilators. Attempting to mitigate this need, all the alternative respiratory support modalities are employed to save lives in hospitals around the globe. Continuous positive airway pressure (CPAP) devices are frequently used in patients with respiratory failure, and although conflicting data exist for their use in coronavirus infection, in a resource scarce environment, they could be a choice to avert intubation and save patients.

\section{Case series}

Six patients suffering from fever, cough, and mild respiratory distress, presented to the Emergency Department (ED) of a tertiary center in western Greece during March 2020. All patients were diagnosed positive for SARS-CoV-2, and on admission were alert, oriented, and hemodynamically stable. Their demographic data, past medical history, and clinical examination findings on admission are presented in Table 1. All patients were 
Table 1. Demographic data, past medical history, and major findings of clinical examination on admission

\begin{tabular}{|c|c|c|c|c|c|}
\hline & Age/sex & BMI/tobacco use & Past medical history & Previous medication & Symptoms on admission \\
\hline Patient 1 & $44 / M$ & 29.3 / No & Hypertension & Olmesartan $20 \mathrm{mg}$ od & $\begin{array}{l}\text { Chest pain, temperature } 38.3^{\circ} \mathrm{C} \text {, } \\
\text { dyspnea, mild productive cough. } \\
\text { Chest auscultation: crackles } \\
\text { on middle and lower lobes bilaterally }\end{array}$ \\
\hline Patient 2 & $74 / M$ & $\begin{array}{c}23.4 \text { / Yes (10 } \\
\text { packs/year) }\end{array}$ & $\begin{array}{l}\text { Benign prostate } \\
\text { hypertrophy, } \\
\text { hypertension }\end{array}$ & $\begin{array}{l}\text { Tamsulosin } 0.4 \mathrm{mg} \text { od, } \\
\text { Amlodipine } 10 \mathrm{mg} \text { od }\end{array}$ & $\begin{array}{c}\text { Diarrhea, temperature } 38.8^{\circ} \mathrm{C} \\
\text { myalgias, non-productive cough. } \\
\text { Chest auscultation: } \\
\text { lower lung crepitations }\end{array}$ \\
\hline Patient 3 & $74 / F$ & 25.4 / No & $\begin{array}{l}\text { Hypertension, } \\
\text { hypothyroidism }\end{array}$ & $\begin{array}{l}\text { Thyrohormone } 0.1 \mathrm{mcg} \text { od, } \\
\text { Amlodipine/valsartan 10/160 }\end{array}$ & $\begin{array}{c}\text { Fatique, non-productive cough, } \\
\text { temperature } 38.2^{\circ} \mathrm{C} \text {. } \\
\text { Chest auscultation: crackles } \\
\text { on middle and lower lobes bilaterally }\end{array}$ \\
\hline Patient 4 & $64 / M$ & 23.8 / No & $\begin{array}{l}\text { Coronary disease, } \\
\text { hypertension, } \\
\text { dyslipidemia }\end{array}$ & $\begin{array}{l}\text { Carvedilol } 12.5 \mathrm{mg} \text { bd, } \\
\text { valsartan } 160 \mathrm{mg} \text { od, } \\
\text { simvastatin } 20 \mathrm{mg} \text { od, } \\
\text { ASA } 100 \mathrm{mg} \text { od }\end{array}$ & $\begin{array}{c}\text { Temperature } 38.3^{\circ} \mathrm{C} \\
\text { mild dyspnea, non-productive cough. } \\
\text { Chest auscultation: crackles } \\
\text { on left lower lobe }\end{array}$ \\
\hline Patient 5 & $79 / M$ & $\begin{array}{l}26.9 \text { / Former } \\
\text { smoker }\end{array}$ & $\begin{array}{l}\text { Hypertension, } \\
\text { dyslipidemia, } \\
\text { peripheral artery } \\
\text { Disease }\end{array}$ & $\begin{array}{l}\text { ASA } 100 \mathrm{mg} \text { od, } \\
\text { felodipine } 5 \mathrm{mg} \text { od, } \\
\text { rosuvastatin } 5 \mathrm{mg} \text { od }\end{array}$ & $\begin{array}{c}\text { Temperature } 38^{\circ} \mathrm{C} \text {, non-productive } \\
\text { cough, fatigue, mild dyspnea. } \\
\text { Chest auscultation: crackles } \\
\text { on lower lobes bilaterally }\end{array}$ \\
\hline Patient 6 & $50 / M$ & $32 /$ No & Hypothyroidism & Thyrohormone $0.1 \mathrm{mcg}$ od & $\begin{array}{l}\text { Dyspnea, non-productive cough, } \\
\text { temperature } 38.3^{\circ} \mathrm{C} \text {. } \\
\text { Chest auscultation: some crackles } \\
\text { on lower lobes bilaterally }\end{array}$ \\
\hline
\end{tabular}

ASA — acetylsalicylic acid; bd — twice a day; BMI — body mass index; od — once daily

isolated in the COVID-19 ward of our hospital, and during their stay they developed respiratory failure. Their $\mathrm{PO}_{2} / \mathrm{FiO}_{2}$ ratio varied between 130 to 160 , they were tachypneic with bilateral infiltrations on chest X-rays. Based on the clinical status and single organ involvement, a decision was made to support them with CPAP oxygen therapy via face mask. StarMed's Ventumask 30 CPAP mask with a Venturi flow driver and adjustable PEEP valve was used in all patients, and to minimize the risk of virus dispersion, all subjects were treated in a negative pressure room (Figure 1). Upon admission all patients were on hydroxychloroquine, lopinavir/ritonavir, azithromycin and ceftaroline or ceftriaxone. Oxygen saturation, blood pressure, heart rate and urine output were continuously monitored. Additionally, the respiratory rate and patient's compliance with CPAP therapy was recorded by the staff nurse. CPAP therapy was well tolerated by all patients and no signs of superinfection of any etiology were noticed based on daily clinical examination and laboratory tests. Blood gas analysis was performed twice daily and in case of any clinically significant event. The attending physicians adjusted the fraction of inspired oxygen and the level of CPAP in accordance to patient's respiratory improvement. All persons were monitored with chest X-rays. Patient number 6 was the only one that received a chest CT scan during his hospitalization (Figures 2-4). Their stay in the negative pressure room and CPAP treatment ranged from 3 to 10 days and 3 to 9 days, respectively (Table 2). All 6 patients, representing 10.3\% of the total COVID-19 admissions of that period, were discharged from the negative pressure room with nasal cannula or Venturi face mask, clinically improved. Finally, after a short stay (up to ten days) in COVID-19 ward, all patients were discharged from our hospital.

\section{Discussion}

The clinical spectrum of COVID-19 is broad, ranging from asymptomatic to severe disease with high mortality. In severely ill patients exhibiting signs of cytokine storm, respiratory function can deteriorate rapidly, and the current evidence proposes that dyspneic patients over 60 years old with comorbidities have to be monitored closely, especially during the first weeks after symptoms onset [1,2]. Respiratory viruses can cause acute respiratory distress syndrome (ARDS), and in the last decade, zoonotic coronaviruses were 

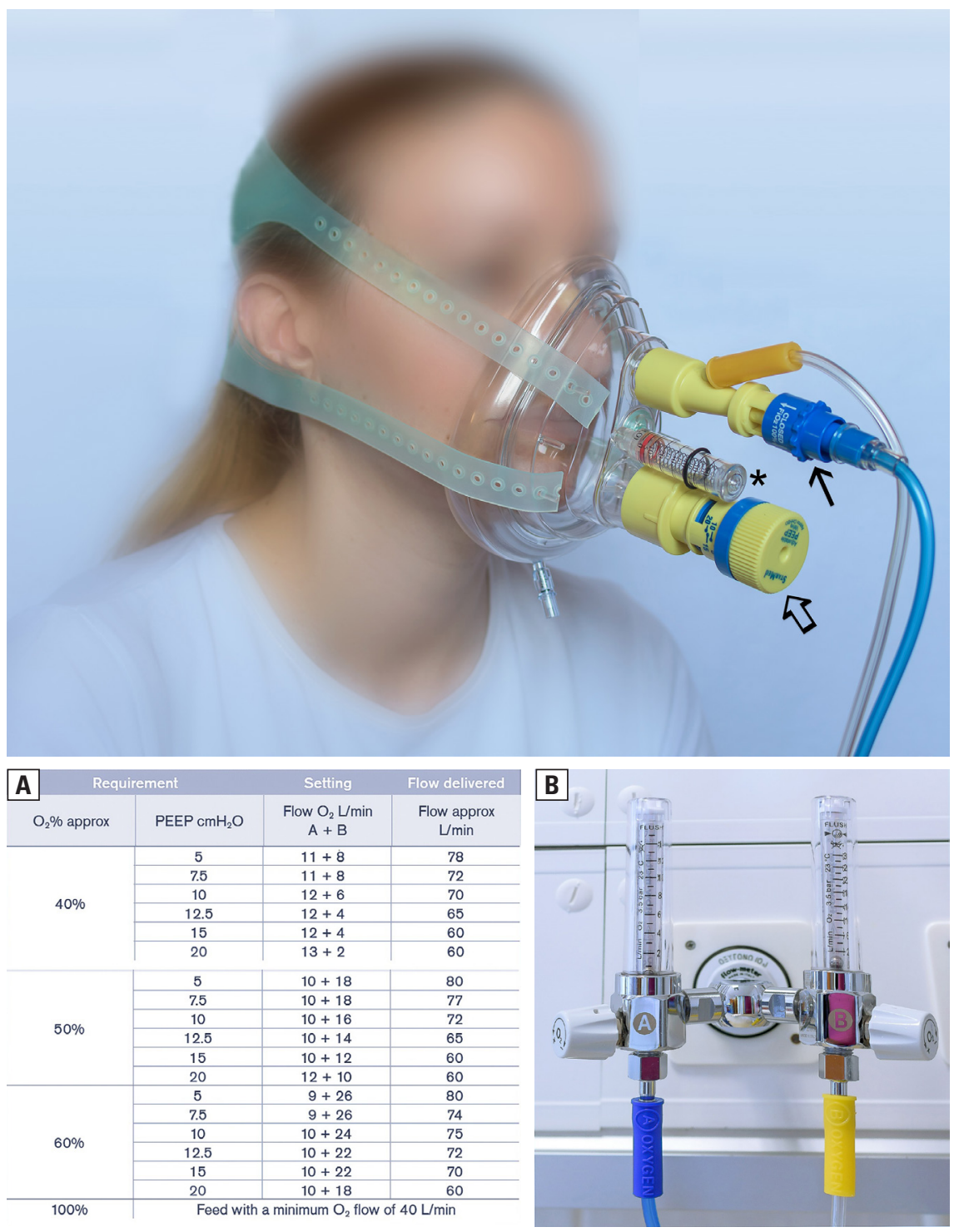

Figure 1. StarMed's Ventumask 30 CPAP mask with Venturi flow driver (black arrow) and adjustable PEEP valve (white arrow). The device is connected to a dual oxygen flow meter $(\mathbf{B})$ and using the settings table $(\mathbf{A})$, flows can reach up to $80 \mathrm{~L} / \mathrm{min}$ and $\mathrm{FiO}_{2}$ can be adjusted from $30 \%$ to $100 \%$. The positive end-expiratory pressure can be set up to $20 \mathrm{cmH}_{2} \mathrm{O}$ and is monitored with the pressure gauge $\left({ }^{*}\right)$

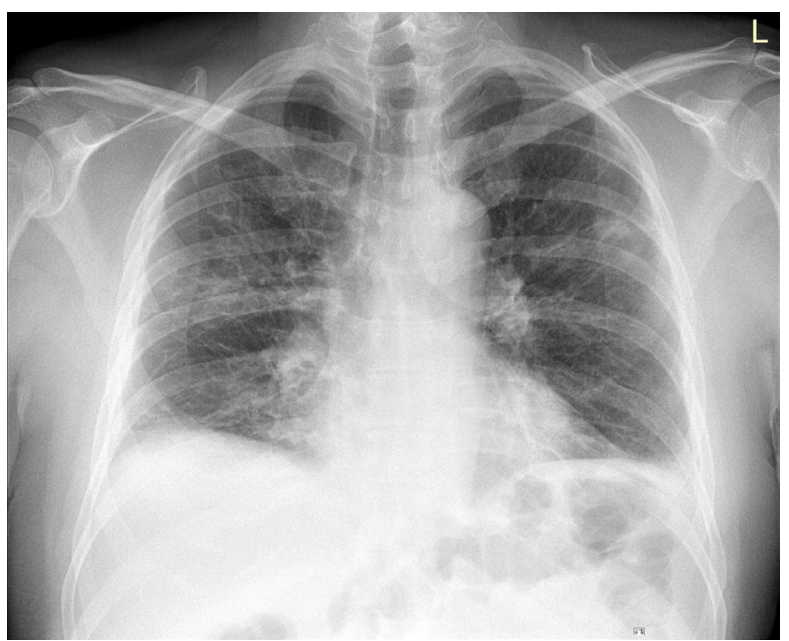

Figure 2. Chest X-ray on hospital admission (day 0) able to cross the species barrier causing severe acute respiratory Syndrome (SARS), Middle East respiratory syndrome (MERS) and recently the pandemic COVID-19. In the event of respiratory failure, prior to intubation and mechanical ventilation in carefully selected patients, a non-invasive ventilation (NIV) or a CPAP trial could be attempted. CPAP and NIV therapy are well documented in patients with respiratory failure, in immuno-compromised patients, in weaning patients from mechanical ventilation, and in critically ill patients with mild ARDS [3, 4].

A CPAP machine maintains a positive pressure in the airway, which can be adjusted while the fraction of inspired oxygen can be raised up to $100 \%$. A tube carries the oxygen-air mixture 

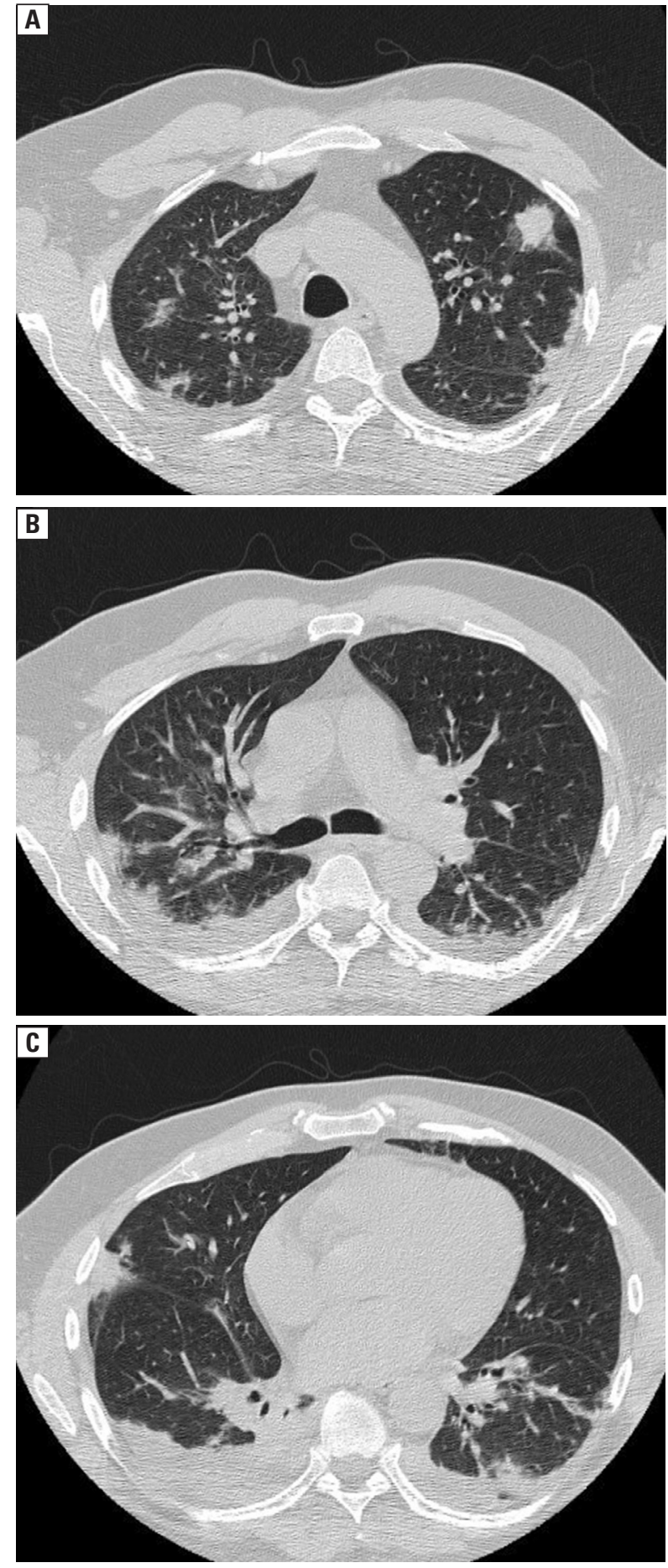

Figure 3. Chest computed tomography scan before his admission to the negative pressure room (day 4)

to an oronasal mask usually that must create a good seal with the patient's face. Beside oronasal masks, other frequently used interfaces include helmets, nasal masks, and full-face masks. CPAP decreases the work of breathing and improves oxygenation by ameliorating lung compliance, allows alveolar recruitment, counteracts the intrinsic positive end expiratory pressure (PEEP)

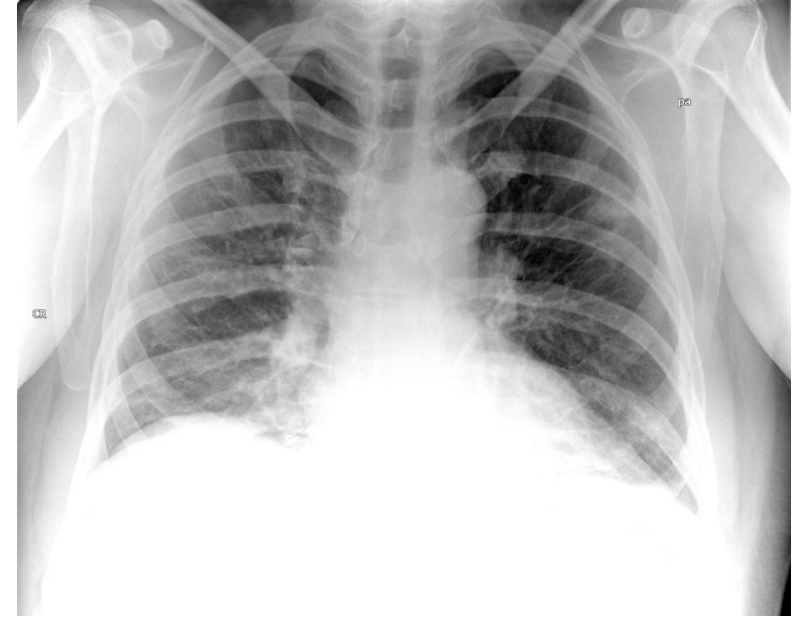

Figure 4. Chest X-ray upon discharge from the negative pressure room (day 8)

and decreases preload and afterload in cases of congestive heart failure [4]. In patients presenting to the emergency department (ED) with acute respiratory failure and without signs of neurologic and/or hemodynamic compromise, a trial of CPAP should be attempted before intubation and mechanical ventilation [5]. Continuous positive airway pressure (CPAP) should be preferably used in a negative pressure isolated hospital room when treating cases of SARS-COV-2 infection due to the high dispersion of the virus when using high flow devices. Alternatively, CPAP therapy could be applied with the use of a helmet combined with a filter on the exhalation port [6].

There are limited and conflicting data regarding the use of NIV or CPAP in respiratory viral infections (RVI). In the study by Kumar et al., the use of NIV in patients with severe influenza A (H1N1) showed NIV failure in up to $85 \%$ [7]. In a multicenter observational study of critically ill patients due to influenza infection hypoxemic respiratory failure, 806 of 1898 patients underwent initial NIV, and $56.8 \%$ of them required finally intubation and invasive ventilation. The more severe cases $(\mathrm{SOFA} \geq 5$ ) had a higher risk of NIV failure. Also NIV failure was associated with increased ICU mortality compared to invasive mechanical ventilation [8]. NIV has been shown to have positive results in the management of some patients with SARS, while in a study based on a multicenter cohort of 302 MERS critically ill patients, NIV was used initially in $35 \%$ of subjects, but the vast majority of them (92.4\%) required invasive mechanical ventilation $[9,10]$.

In a recent retrospective observational study that included 24 patients with respiratory fail- 
Table 2. Patients' data during stay in negative pressure room

\begin{tabular}{|c|c|c|c|c|c|c|c|c|c|c|}
\hline & $\begin{array}{c}\mathrm{PO}_{2} / \mathrm{FiO}_{2} \\
\text { on } \\
\text { admission }\end{array}$ & $\begin{array}{c}\text { Days } \\
\text { in negative } \\
\text { pressure } \\
\text { room }\end{array}$ & $\begin{array}{l}\text { Days } \\
\text { on } \\
\text { CPAP }\end{array}$ & $\begin{array}{l}\text { CPAP } \\
\text { cm H } \mathrm{H}_{2} \mathrm{O}\end{array}$ & $\begin{array}{c}\text { Hours per } \\
\text { day on } \\
\text { CPAP }\end{array}$ & $\begin{array}{c}\text { Side } \\
\text { effects }\end{array}$ & $\begin{array}{l}\text { Antibiotic } \\
\text { treatment }\end{array}$ & $\begin{array}{c}\text { Anti-viral } \\
\text { agent }\end{array}$ & $\begin{array}{c}\text { Hydroxy } \\
\text { chloroquine }\end{array}$ & $\begin{array}{c}\mathrm{PO}_{2} / \mathrm{FiO}_{2} \\
\text { on discharge } \\
\text { from negative } \\
\text { pressure room }\end{array}$ \\
\hline Patient 1 & 145 & 10 & 9 & $5-7.5$ & 24 & $\begin{array}{c}\text { Nasal } \\
\text { bridge } \\
\text { pressure } \\
\text { ulcer }\end{array}$ & $\begin{array}{l}\text { Ceftaroline, } \\
\text { azithromycin }\end{array}$ & $\begin{array}{l}\text { Lopinavir/ } \\
\text { ritonavir }\end{array}$ & Yes & 200 \\
\hline Patient 2 & 160 & 6 & 5 & 5 & 24 & None & $\begin{array}{c}\text { Ceftarolin, } \\
\text { azithromycin }\end{array}$ & $\begin{array}{l}\text { Lopinavir/ } \\
\text { ritonavir }\end{array}$ & Yes & 320 \\
\hline Patient 3 & 140 & 7 & 7 & $7.5-10$ & 24 & $\begin{array}{c}\text { Nasal } \\
\text { bridge } \\
\text { pressure } \\
\text { ulcer }\end{array}$ & $\begin{array}{l}\text { Ceftriaxone, } \\
\text { azithromycin }\end{array}$ & $\begin{array}{l}\text { Lopinavir/ } \\
\text { ritonavir }\end{array}$ & Yes & 250 \\
\hline Patient 4 & 150 & 5 & 5 & $7.5-10$ & 24 & None & $\begin{array}{c}\text { Ceftarolin, } \\
\text { azithromycine }\end{array}$ & $\begin{array}{l}\text { Lopinavir/ } \\
\text { ritonavir }\end{array}$ & Yes & 180 \\
\hline Patient 5 & 160 & 3 & 3 & 7.5 & 24 & None & $\begin{array}{l}\text { Ceftriaxone, } \\
\text { azithromycin }\end{array}$ & $\begin{array}{l}\text { Lopinavir/ } \\
\text { ritonavir }\end{array}$ & Yes & 205 \\
\hline Patient 6 & 120 & 4 & 4 & 7.5 & 24 & None & $\begin{array}{c}\text { Ceftarolin, } \\
\text { azithromycine }\end{array}$ & $\begin{array}{l}\text { Lopinavir/ } \\
\text { ritonavir }\end{array}$ & Yes & 170 \\
\hline
\end{tabular}

CPAP — continuous positive airway pressure

ure type 1 due to SARS-CoV-2, CPAP treatment successfully averted intubation in over half of the patients. All the patients were treated in a negative pressure room at the Royal Liverpool Hospital. 14 patients were weaned off CPAP and discharged. Their median time on CPAP and bed stay were 4.5 and 10.5 days, respectively [11]. Furthermore, a small two period retrospective case control study that included 52 patients (14 controls and 38 cases) showed that CPAP is feasible in deteriorating COVID-19 patients and can avoid intubation at 7 days and at 14 days. More patents in the control group were intubated or died in comparison to the experimental group (57\% vs $23 \%, \mathrm{p}=0.043)$. Median use of CPAP was 5 (2-7.5) days and for 8 (4-11) hours daily [12].

Finally, new data for COVID-19 are becoming available, raising concerns regarding the lack of ICU beds worldwide, and the high mortality rates observed after intubation and mechanical ventilation [13, 14]. The current available evidence indicates that a CPAP therapy can be used in COVID-19 respiratory failure, and this strategy may avert intubation.

\section{Conclusions}

In anticipation of new studies that will shed more light on a definitive COVID-19 treatment, management principles for this new clinical entity in case of ARDS are mainly supportive and should be similar to the management of ARDS from other causes. Until a specific antiviral treatment is available, the use of invasive and non-invasive ventilation should be tailored according to patient's needs and clinical status. There is a true need for efficient trial designs to test the role of continuous positive airway pressure support in patients with respiratory failure due to SARS-CoV-2, alone or in combination with other treatment options.

\section{Conflict of interest}

None declared.

\section{References:}

1. Wu Z, McGoogan JM. Characteristics of and important lessons from the coronavirus disease 2019 (COVID-19) outbreak in china: summary of a report of 72314 cases from the Chinese Center for Disease Control and Prevention. JAMA. 2020; 323(13): 1239-1242, doi: 10.1001/jama.2020.2648, indexed in Pubmed: 32091533.

2. Huang ACC, Huang CG, Yang CT, et al. Clinical features of patients infected with 2019 novel coronavirus in Wuhan, China. Lancet. 2020; 395(10223): 497-506, doi: 10.1016/S01406736(20)30183-5, indexed in Pubmed: 31986264.

3. Mas A, Masip J. Noninvasive ventilation in acute respiratory failure. Int J Chron Obstruct Pulmon Dis. 2014; 9: 837-852, doi: 10.2147/COPD.S42664, indexed in Pubmed: 25143721.

4. Rochwerg B, Brochard L, Elliott MW, et al. Official ERS/ ATS clinical practice guidelines: noninvasive ventilation for acute respiratory failure. Eur Respir J. 2017; 50(2), doi: 10.1183/13993003.02426-2016, indexed in Pubmed: 28860265.

5. Hess DR, Hess DR, Fessler HE, et al. Noninvasive positive pressure ventilation for acute respiratory failure. Int Anesthesiol Clin. 1999; 37(3): 85-102, doi: 10.1097/00004311-19990373000009, indexed in Pubmed: 10445175. 
6. Lucchini A, Giani M, Isgrò S, et al. The "helmet bundle" in COVID-19 patients undergoing non invasive ventilation. Intensive Crit Care Nurs. 2020; 58: 102859, doi: 10.1016/i. iccn.2020.102859, indexed in Pubmed: 32249028.

7. Kumar A, Zarychanski R, Pinto R, et al. Critically ill patients with 2009 influenza A(H1N1) infection in Canada. JAMA 2009; 302(17): 1872-1879, doi: 10.1001/jama.2009.1496, indexed in Pubmed: 19822627.

8. Rodríguez A, Ferri C, Martin-Loeches I, et al. Risk factors for noninvasive ventilation failure in critically ill subjects with confirmed influenza infection. Respir Care. 2017; 62(10): 1307-1315, doi: 10.4187/respcare.05481, indexed in Pubmed: 28698265.

9. Cheung TMT, Yam LYC, So LKY, et al. Effectiveness of noninvasive positive pressure ventilation in the treatment of acute respiratory failure in severe acute respiratory syndrome. Chest. 2004; 126(3): 845-850, doi: 10.1378/chest.126.3.845, indexed in Pubmed: 15364765.

10. Alraddadi BM, Qushmaq I, Al-Hameed FM, et al. Noninvasive ventilation in critically ill patients with the Middle East respiratory syndrome. Influenza Other Respir Viruses. 2019; 13(4) 382-390, doi: 10.1111/irv.12635, indexed in Pubmed: $\underline{30884185}$.
11. Nightingale R, Nwosu N, Kutubudin F, et al. Is continuous positive airway pressure (CPAP) a new standard of care for type 1 respiratory failure in COVID-19 patients? A retrospective observational study of a dedicated COVID-19 CPAP service. BMJ Open Respir Res. 2020; 7(1), doi: 10.1136/bmjresp-2020-000639, indexed in Pubmed: 32624495.

12. Oranger M, Gonzalez-Bermejo J, Dacosta-Noble P, et al. Continuous positive airway pressure to avoid intubation in SARSCoV-2 pneumonia: a two-period retrospective case-control study. Eur Respir J. 2020; 56(2), doi: 10.1183/13993003.016922020, indexed in Pubmed: $\underline{32430410}$

13. Guan WJ, Ni ZY, Hu Yu, et al. Clinical characteristics of coronavirus disease 2019 in China. N Engl J Med. 2020; 382(18): 1708-1720, doi: 10.1056/NEJMoa2002032, indexed in Pubmed: 32109013 .

14. Zhou F, Yu T, Du R, et al. Clinical course and risk factors for mortality of adult inpatients with COVID-19 in Wuhan, China: a retrospective cohort study. Lancet. 2020; 395(10229): 1054-1062, doi: 10.1016/S0140-6736(20)30566-3, indexed in Pubmed: $\underline{32171076 .}$ 